\title{
Zig-zagging across Central Europe: recent range extension, dispersal speed and larval hosts of Aproceros leucopoda (Hymenoptera,Argidae) in Germany
}

\author{
Stephan M. Blank', Thomas Köhler ${ }^{2}$, Toralf Pfannenstill', Nadine Neuenfeldt ${ }^{3}$, \\ Bianka Zimmer ${ }^{3}$, Ewald Jansen ${ }^{4}$, Andreas Taeger', Andrew D. Liston'
}

I Senckenberg Deutsches Entomologisches Institut, Eberswalder Str. 90, 15374 Müncheberg, Germany 2 Beuth Hochschule für Technik Berlin, Fachbereich V-Life Sciences and Technology, Luxemburger Str. 10, 13353 Berlin, Germany 3 Landesamt für Ländliche Entwicklung, Landwirtschaft und Flurneuordnung (LELF), Müllroser Chaussee 54, 15236 Frankfurt/Oder, Germany 4 Alter Marktweg 8, 04319 Leipzig, Germany

Corresponding authors: Stephan M. Blank (sblank@senckenberg.de); Andrew D. Liston (aliston@senckenberg.de)

Academic editor: S. Schmidt | Received 1 October 2014 | Accepted 19 October 2014 | Published 22 December 2014

http://zoobank.org/E56A6898-OFFF-4750-8F03-214B46E1CB27

Citation: Blank SM, Köhler T, Pfannenstill T, Neuenfeldt N, Zimmer B, Jansen E, Taeger A, Liston AD (2014) Zigzagging across Central Europe: recent range extension, dispersal speed and larval hosts of Aproceros leucopoda (Hymenoptera, Argidae) in Germany. Journal of Hymenoptera Research 41: 57-74. doi: 10.3897/JHR.41.8681

\begin{abstract}
Aproceros leucopoda, the zig-zag sawfly, an invasive pest of elms (Ulmus spp.), was found in two separate areas of Germany through July 2014, i.e., a northern area including the states of Berlin, Brandenburg, Mecklenburg-West Pomerania, Saxony and Saxony-Anhalt, and a southern area in Bavaria. A speed of self-dispersal of 45-90 km/yr has been calculated from earlier and present records. Observations of $A$. leucopoda in Belgium and the Netherlands during 2013, which are 360-610 km distant from records in Germany of that year, are interpreted as resulting from human-mediated jump dispersal. Larvae, feeding traces and cocoons were frequently found on the native elm species $U$. minor and $U$. glabra, whereas none could be detected on $U$. laevis. Other occurrences were often on Resista elms, causing severe defoliation in a recent planting. New host plant records for A. leucopoda are: U. minor 'Webbiana', U. minor var. suberosa, and the Resista cultivars $U$. 'New Horizon', $U$. 'Regal' and $U$. 'Rebona'. The future dispersal of A. leucopoda throughout most of Germany is expected, because at least $U$. glabra and $U$. minor are widespread in this country.
\end{abstract}

\section{Keywords}

Argidae, Aproceros leucopoda, zig-zag sawfly, invasive species, pest species, Ulmus laevis, Ulmus Resista ${ }^{\circledR}$ hybrids, distribution in Germany, self-dispersal, human-mediated jump dispersal

Copyright Stephan M. Blank et al. This is an open access article distributed under the terms of the Creative Commons Attribution License (CC BY 4.0), which permits unrestricted use, distribution, and reproduction in any medium, provided the original author and source are credited. 


\section{Introduction}

The invasive zig-zag sawfly Aproceros leucopoda Takeuchi, 1939, is of East Asian origin and was first found in Europe in 2003 (Blank et al. 2010). Its larvae feed on elms (Ulmus spp.) and sometimes severely defoliate their hosts. By 2009, the known European distribution of $A$. leucopoda extended from eastern Ukraine to Austria and from Poland to Romania. Since then, it has also been found in northern Italy (Zandigiacomo et al. 2011), Slovenia (de Groot et al. 2012), Croatia (Matošević 2012), Moldova (Timuş et al. 2008, misidentified as Arge sp.) and widely in European Russia from Rostov-on-Don to Moscow (Artokhin et al. 2012, Anonymous 2013). In Germany, it had been recorded only from the extreme southeast of Bavaria (Kraus et al. 2012) but not from the eastern states close to the Polish border, although the records of $A$. leucopoda from Poland made in 2003 are amongst the first from Europe. In 2013, $A$. leucopoda was observed near northwestern Germany in Belgium (Boevé 2014) and in the Netherlands (Mol and Vonk 2013).

Aproceros leucopoda is classified in the Argidae, which comprise roughly 70 species in Europe and about 900 worldwide (Taeger et al. 2006, 2010). In Europe, a few species of Arge have been reported to occur as pests of ornamental plants and forest trees (e.g., Pschorn-Walcher 1982, Taeger et al. 1998). Outbreaks of Arge pullata (Zaddach, 1859) may occur on birch trees. When the trees grow in pastures, farm livestock can be poisoned after ingestion of larvae (Brummerstedt et al. 1987, Thamsborg et al. 1987, Kannan et al. 1988, Hara and Shinohara 2008). Similar to Aproceros leucopoda in its association with elms as the larval hosts, is Arge captiva (F. Smith, 1874) (Shinohara et al. 2009). It became an invasive pest after its accidental introduction to Kazakhstan, where the larvae have severely damaged Dwarf Elm trees (U. pumila) planted in the new capital Astana (Blank et al. 2011).

To effect an early warning, in 2011 A. leucopoda was placed on the EPPO Alert List, which displays information on pest organisms that possibly represent a risk to the European and Mediterranean EPPO member countries (EPPO 2014). The Federal Research Centre for Cultivated Plants of Germany assessed the phytosanitary risk attached to this invasive species as high (Schrader and Schröder 2013). As a result of the monitoring of $A$. leucopoda in Germany, we report here on the recent range extension into large areas of Germany, map the current distribution in this country and provide new information on host plant choice. The current distribution pattern is discussed and the speed of the range extension is estimated.

\section{Methods}

Since 2009, A.D. Liston [ADL] and S.M. Blank [SMB] have paid special attention to elms in eastern Brandenburg, in the expectation that Aproceros leucopoda would become established in this region. Searches were made for feeding traces, larvae, cocoons and imagines (Figs 1-2). These were described and illustrated in detail by Blank et al. 
(2010). Following the first observations in eastern Brandenburg in May 2013, the frequency of searches was increased and the area in Germany that was searched was extended, covering initially $\mathrm{Br}$ [Berlin and Brandenburg], Ni [Lower Saxony, Niedersachsen], Sn [Saxony], St [Saxony-Anhalt] (abbreviations of the German states as used in the checklist of the sawflies of Germany, Blank et al. 2001). In early October 2013, SMB checked the western distribution of $A$. leucopoda while on a round-trip through By [Bavaria], BW [Baden-Wurttemberg], He [Hesse], Ni, NW [North Rhine-Westphalia] and SH [Schleswig-Holstein]. Observations of E. Jansen [EJ] during 2012-2013 primarily covered BW, Sn and St. T. Köhler [TK] contributed observations from $\mathrm{Br}$ and MV [Mecklenburg-West Pomerania] in 2013-2014, T. Pfannenstill [TP] and B. Zimmer [BZ] from southern $\mathrm{Br}$ in 2013-2014, and A. Taeger [AT] from St in 2014. Usually, presence and absence of $A$. leucopoda on a study site was noted by ADL, EJ, $\mathrm{SMB}, \mathrm{TK}$, but only presence was recorded by AT, BZ and TP. To determine presence or absence, elms on randomly chosen sites were screened for feeding traces, larvae, cocoons or imagines from late May to early October. The time spent searching for A. leucopoda depended on patch size of an individual elm stand, usually varying from 2-5 minutes for small bushes to 5-10 minutes for large trees. Usually, the number of signs of $A$. leucopoda was noted for a patch, but sometimes the search was stopped as soon as a single sign was detected. ADL, BZ, SMB and TK also determined the elm species or cultivar on the study site. The nomenclature of Ulmus taxa follows Mackenthun (2010). Unless attributed to other recorders, the observations were made by the authors. Voucher specimens of larvae and imagines from some localities as well as extensive photographic documentation of occurrences are held at the Senckenberg Deutsches Entomologisches Institut. Statistical analysis of the observation data follows Zöfel (1988).

As a contribution towards encouragement of 'citizen science', an attempt was made to mobilize additional potential observers by placing an illustrated description of A. leucopoda and its distinctive feeding traces in the German popular press, with an appeal that observations be reported to the Senckenberg Deutsches Entomologisches Institut in Müncheberg (Bartel 2013). Records sent by citizen scientists as photos or herbarium vouchers were collected and re-identified by ADL and SMB.

For the outbreak area in Schlieben, Brandenburg, N. Neuenfeldt and TP assessed the density of specimens hibernating in cocoons in the ground. Samples of soil and leaf litter were taken from below three elm trees in December 2013. Each sample was from a $5-10 \mathrm{~cm}$ deep plot of ca $0.40 \mathrm{~m}^{2}$ area. Cocoons of $A$. leucopoda were extracted from a mixed sample of ca $1.8 \mathrm{~kg}$ soil and litter and stored outdoors in a tent until imagines emerged.

The distribution map was prepared from a draft map produced by Carto FaunaFlora 1.2 (Barbier and Rasmont 1996), and subsequently enhanced with Adobe Photoshop ${ }^{\circ}$ and Corel Draw ${ }^{\circ}$. Countries outside Germany with records of $A$. leucopoda are labelled with the international vehicle registration codes. German states are labelled with the acronyms explained above. Distribution data for Ulmus glabra and U. minor were obtained from FLORKART (BfN and NetPhyD 2013). Free use of these data for the purpose of scientific analyses is licensed under the provisions of Creative 
Commons BY-NC-SA 3.0 DE. Only data sets with unambiguous identifications and observation dates later than 1979 were used to display the contemporary distribution of these elms, which have disappeared in some regions of Germany since 1980.

To estimate the speed of annual range extension it seems prudent to compare a number of estimates based on different hypothetical dispersal scenarios. Based on the known records, we measured the distance, $A$, between the earliest records from Hungary and Poland (Blank et al. 2010) and the most distant observation sites in Germany; $B$, between the closest neighbouring sites, where $A$. leucopoda was recorded within the period of a few years; $C$, the minimum and maximum distances between the records in Belgium (Boevé 2014) and the Netherlands (Mol and Vonk 2013) and the closest observation sites in Germany known in 2013. The annual dispersal speed was calculated from these distances and the related years of observation.

\section{Results}

\section{Distribution of $A$. leucopoda in Germany}

Through mid-July 2014 Aproceros leucopoda was recorded from the easterly German federal states of Berlin (recorded from 8 study sites), Brandenburg (39), MecklenburgWest Pomerania (1), Saxony (5) and Saxony-Anhalt (2) and also from southeast Bavaria (5). These numbers also include data published by Kraus et al. (2012) and Sobczyk and Nuss (2014). At most localities, the presence of $A$. leucopoda was revealed by the conspicuous 'zig-zag' feeding traces (Fig. 1) made by the young larvae. However, older larvae or cocoons also drew attention to its presence, particularly later in the year. Only very few imagines were observed in the field, although several were reared from cocoons collected from the undersides of elm leaves.

The data on the presence and absence of $A$. leucopoda throughout Germany and in the neighbouring countries are mapped in Fig. 3. Aproceros leucopoda was not found on 140 study sites, which are distributed in the above mentioned as well as in more western federal states of Germany (Fig. 3, blue crosses). The record by Pimpl (2014) for the Erzgebirge in Saxony is based on a misidentification of Cladius rufipes Serville, 1823 (Tenthredinidae, re-identification by SMB). Currently, the following additional records for Germany exist (sorted by federal state and 'Landkreis', a subdivision of a German federal state):

Bavaria: Landkreis Deggendorf: Niederalteich NW 3 km, rest area 'Seebach' on highway A3, $48.788^{\circ} \mathrm{N}, 13.011^{\circ} \mathrm{E}, 315 \mathrm{~m}$ alt., $07.08 .2013,3$ larvae and feeding traces, Ulmus sp. Landkreis Freyung-Grafenau: Irlesberg S $700 \mathrm{~m}$, along federal highway B12, $48.720^{\circ} \mathrm{N}, 13.531^{\circ} \mathrm{E}, 425 \mathrm{~m}$ alt., $07.08 .2013,1$ larva and feeding traces, $U$. minor. Landkreis Regensburg: Wörth SE, rest area 'Tiefenthal' on highway A3, $48.993^{\circ} \mathrm{N}$, $12.420^{\circ} \mathrm{E}, 335 \mathrm{~m}$ alt., $07.08 .2013,1$ larva and 5 feeding traces, $U$. sp.

Berlin: Friedrichshagen, environs of S-train station, $52.456^{\circ} \mathrm{N}, 13.625^{\circ} \mathrm{E}$, 20.05.2013, numerous, partly late instar larvae, U. glabra; Kreuzberg, Columbiadamm, 


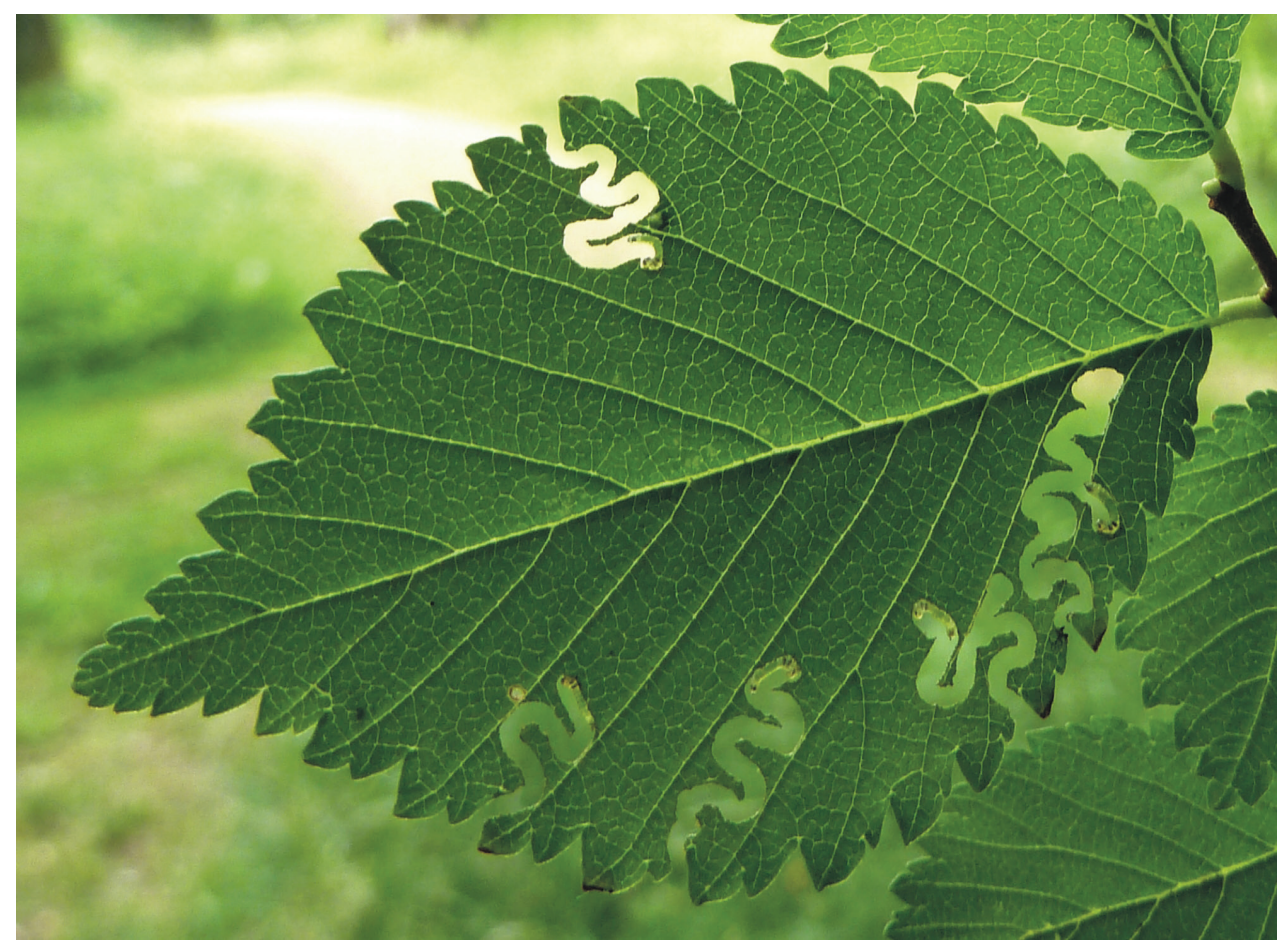

Figure I. Feeding traces, with young larvae of Aproceros leucopoda, on leaf of Ulmus minor, Forstbotanischer Garten in Eberswalde (Brandenburg). Photo: SDEI/Liston.

$52.483^{\circ} \mathrm{N}, 13.401^{\circ} \mathrm{E}, 29.8 .2013$, feeding traces, $U$. 'New Horizon' (planted in $2007-$ 2009); Lichterfelde, Botanic Garden, Arboretum, $52.453^{\circ} \mathrm{N}, 13.305^{\circ} \mathrm{E}, 24.07 .2013$, feeding traces, $U$. davidiana var. japonica, U. minor 'Webbiana' and $U$. sp. (not $U$. laevis); Lichterfelde, Botanic Garden, Balkan section, $52.453^{\circ} \mathrm{N}, 13.305^{\circ} \mathrm{E}, 24.07 .2013$, feeding traces, U. minor 'suberosa'; Pankow, Märchenweg, along Fließgraben, $52.576^{\circ} \mathrm{N}, 13.475^{\circ} \mathrm{E}, 10.08 .2013,1$ feeding trace, U. minor, Pankow, Treskowstraße, $52.561^{\circ} \mathrm{N}, 13.429^{\circ} \mathrm{E}, 11.08 .2013,2$ feeding traces, $U$. 'Rebona'; Wedding, intersection of Tegeler Straße and Lynarstraße, $52.540^{\circ} \mathrm{N}, 13.358^{\circ} \mathrm{E}, 24.07 .2013$, feeding traces, U. pumila var. arborea; Wedding, Utrechter Straße, $52.548^{\circ} \mathrm{N}, 13.355^{\circ} \mathrm{E}, 14.8 .2013$, feeding traces, U. pumila var. arborea.

Brandenburg: Landkreis Barnim: Biesenthal ESE, Grüntal, Feldgehölz, $52.740^{\circ} \mathrm{N}$, $13.728^{\circ} \mathrm{E}$, 16.07.2013, feeding traces, U. minor, Eberswalde, Forstbotanischer Garten, $52.825^{\circ} \mathrm{N}, 13.791^{\circ} \mathrm{E}, 30 \mathrm{~m}$ alt., 23.06.2013, 30 larvae, U. minor. Landkreis DahmeSpreewald: Brusendorf NW, rest area 'Am Fichtenplan' on highway A10, $52.315^{\circ} \mathrm{N}$, $13.497^{\circ} \mathrm{E}, 50 \mathrm{~m}$ alt., 07.08 .2013 , 3 feeding traces, Ulmus cultivar with smooth leaves, slender crown form. Landkreis Elbe-Elster: Kolochau, federal highway B87 in direction of Herzberg, $51.716^{\circ} \mathrm{N}, 13.281^{\circ} \mathrm{E}, 27.08 .2013$, numerous larvae, feeding traces and cocoons, massive infestation, $U$. 'Resista' cultivar; Schlieben in direction of Herzberg, bicycle path from Kolochau for $3 \mathrm{~km}$ length, $51.727^{\circ} \mathrm{N}, 13.312^{\circ} \mathrm{E}, 29.07 .2013,3$ reared $\circ$, numerous 
larvae, feeding traces and cocoons, massive infestation, U. 'New Horizon'. Stadtkreis Frankfurt/Oder: Frankfurt/Oder, Leipziger Straße, Südring Center, $52.328^{\circ} \mathrm{N}, 14.521^{\circ} \mathrm{E}$, 05.09.2013, 2 cocoons and feeding traces, 1-5\% damage observed on 39 of ca $100 \mathrm{U}$. 'Resista' trees. Landkreis Havelland: Märkisch Luch SW, $52.560^{\circ} \mathrm{N}, 12.602^{\circ} \mathrm{E}, 30 \mathrm{~m}$ alt., 10.08.2013, 1 eonymph, $U$. cultivar planted as alley along street; Tremmen, $52.533^{\circ} \mathrm{N}$, $12.8167^{\circ} \mathrm{E}, 06.09 .2013$, weak infestation on $U$. 'New Horizon' (planted 2010) and $U$. 'Rebona' (planted 2009). Landkreis Märkisch-Oderland: Gabow N, $52.820^{\circ} \mathrm{N}, 14.071^{\circ} \mathrm{E}$, 14.07.2013, 4 larvae, U. minor; Hoppegarten E, Berliner Chaussee, $52.496^{\circ} \mathrm{N}, 14.058^{\circ} \mathrm{E}$, 20.05.2013, 15 leaves with feeding traces, 10 early instar larvae, U. glabra; Jahnsfelde, $52.507^{\circ} \mathrm{N}, 14.228^{\circ} \mathrm{E}, 19.05 .2013,6$ leaves with feeding traces, 3 early instar larvae, $U$. glabra; Müncheberg, car-park of Netto supermarket, $52.506^{\circ} \mathrm{N}, 14.133^{\circ} \mathrm{E}, 18.07 .2013$, feeding traces, $U$. cultivar ('Columella'?); Müncheberg, railway station, $52.524^{\circ} \mathrm{N}, 14.102^{\circ} \mathrm{E}$, 04.07.2013, 3 feeding traces, U. glabra; Müncheberg, Waschbanksee, $52.502^{\circ} \mathrm{N}, 14.139^{\circ} \mathrm{E}$, 14.07.2013, 5 feeding traces, cultivated U. cultivar ('Sapporo Autumn Gold', 'New Horizon' or 'Rebona'?); same site, 15.07.2013, 2 larvae, cultivated U. sp.; Müncheberg, ZALF campus, $52.515^{\circ} \mathrm{N}, 14.115^{\circ} \mathrm{E}, 07.06 .2013,1 q$ swept from U. glabra; same site, 04.07.2013, 2 larvae, U. glabra; same site, 20.06.2014, 4 larvae, U. glabra; Podelzig, entrance of road to railway station, $52.482^{\circ} \mathrm{N}, 14.538^{\circ} \mathrm{E}, 30.07 .2013,10$ feeding traces, $U$. minor; Steinhöfel, alley, $52.400^{\circ} \mathrm{N}, 14.167^{\circ} \mathrm{E}, 30.08 .2013$, feeding traces, $U$. 'Resista' (planted ca 2008); Waldsieversdorf $2 \mathrm{~km} \mathrm{SW}$, road in direction of Rotes Luch, $52.523^{\circ} \mathrm{N}$, $14.039^{\circ} \mathrm{E}, 14.08 .2013,1$ feeding trace, U. glabra. Landkreis Oberhavel: Borgsdorf, S of church, $52.704^{\circ} \mathrm{N}, 13.248^{\circ} \mathrm{E}, 25.06 .2014$, feeding traces, $U$. minor; Borgsdorf, W of quarry pond, $52.704^{\circ} \mathrm{N}, 13.226^{\circ} \mathrm{E}, 25.06 .2014$, U. glabra; Liebenberg, Fichten, rest area of federal highway B167, $52.890^{\circ} \mathrm{N}, 13.267^{\circ} \mathrm{E}, 14.07 .2013$, 1 feeding trace, U. glabra; Oranienburg, Berliner Straße, $52.723^{\circ} \mathrm{N}, 13.250^{\circ} \mathrm{E}, 26.07 .2013$, feeding traces, U. glabra; Oranienburg, Berliner Straße, in front of Poliklinik, $52.742^{\circ} \mathrm{N}, 13.239^{\circ} \mathrm{E}, 23.07 .2013$, feeding traces, $U$. 'New Horizon'; Oranienburg, Holbeinstraße, $52.725^{\circ} \mathrm{N}, 13.248^{\circ} \mathrm{E}, 20.07 .2013,3$ leaves with feeding traces, $U$. minor ( $2 \mathrm{~m}$ high shoots growing from roots); Oranienburg, Idenstraße, $52.771^{\circ} \mathrm{N}, 13.249^{\circ} \mathrm{E}, 23.07 .2013$, larva and several feeding traces, $U$. 'Regal'; Zehlendorf, W and $\mathrm{S}$ of clay pit, $52.799^{\circ} \mathrm{N}, 13.380^{\circ} \mathrm{E}, 20.07 .2013,1$ cocoon, $U$. minor (U. glabra and U. laevis growing nearby not infested). Landkreis Oberspreewald-Lausitz: Calau SW $6 \mathrm{~km}$, rest area on highway A13, $51.700^{\circ} \mathrm{N}, 13.899^{\circ} \mathrm{E}, 135 \mathrm{~m}$ alt., 01.08.2013, feeding traces, two Ulmus cultivars (possibly sorts of Resista due to the narrowly coneshaped crown). Landkreis Oder-Spree: Beeskow, alley, $52.174^{\circ} \mathrm{N}, 14.247^{\circ} \mathrm{E}, 30.08 .2013$, feeding traces, $U$. 'Resista' (planted 2007); Fangschleuse, $S$ of railway station, $52.402^{\circ} \mathrm{N}$, $13.825^{\circ} \mathrm{E}, 20.05 .2013,2$ leaves with feeding traces, U. glabra; Kagel, along road L 323, $52.467^{\circ} \mathrm{N}, 13.917^{\circ} \mathrm{E}, 04.09 .2013,2$ young larvae and feeding traces, $U$. 'Resista' (planted 2010). Landkreis Teltow-Fläming: Ahrensdorf near Ludwigsfelde, $52.317^{\circ} \mathrm{N}, 13.200^{\circ} \mathrm{E}$, 01.10.2013, feeding traces, $U$. 'Rebona', observed by K. Langner; Ahrensdorf, alley along street $\mathrm{K} 7220,52.195^{\circ} \mathrm{N}, 13.172^{\circ} \mathrm{E}, 02.09 .2013$, heavy infestation, of 22 Ulmus trees (planted ca 2008), late instar larvae still present on 01.10.; Blankenfelde SW $4 \mathrm{~km}$, rest area on highway $\mathrm{A} 10,52.308^{\circ} \mathrm{N}, 13.369^{\circ} \mathrm{E}, 30.06 .2013,4$ feeding traces of early instar larvae, U. glabra; Dahlewitz, Friedhofsweg, $52.319^{\circ} \mathrm{N}, 13.436^{\circ} \mathrm{E}, 7.9 .2013$, feeding traces 
on 2 leaves, $U$. minor, Löwendorf, Märtensmühle, $52.204^{\circ} \mathrm{N}, 13.184^{\circ} \mathrm{E}, 27.08 .2013$, larvae and feeding traces, $U$. sp.; Zossen-Neuhof, Cottbuser Straße, $52.144^{\circ} \mathrm{N}, 13.479^{\circ} \mathrm{E}$, 29.08.2013, 2 feeding traces, U. sp. Landkreis Uckermark: Prenzlau, Seelübber Weg, $53.299^{\circ} \mathrm{N}, 13.879^{\circ} \mathrm{E}, 11.08 .2013,3$ feeding traces, U. glabra; Schönermark, railway station, $53.106^{\circ} \mathrm{N}, 14.033^{\circ} \mathrm{E}, 11.08 .2013,2$ feeding traces, $U$. glabra.

Mecklenburg-West Pomerania: Landkreis Mecklenburgische Seenplatte: Neustrelitz, intersection of Strelitzer Straße and Bürgerhorststraße, $53.357^{\circ} \mathrm{N}, 13.072^{\circ} \mathrm{E}$, 27.08.2013, feeding traces, $U$. 'New Horizon'.

Saxony: Landkreis Leipzig: Leipzig, Leipziger Auen, Weiße Brücke, $51.303^{\circ} \mathrm{N}$, $12.356^{\circ} \mathrm{E}, 125 \mathrm{~m}$ alt., 27.06.2014, 2 feeding traces, U. sp.; Leipzig-Rückmarsdorf, Bienitz, $51.353^{\circ} \mathrm{N}, 12.252^{\circ} \mathrm{E}, 120 \mathrm{~m}$ alt., $22.06 .2014,3$ feeding traces, $U$. sp. Landkreis Meißen: Wildberg, $51.100^{\circ} \mathrm{N}, 13.588^{\circ} \mathrm{E}, 120 \mathrm{~m}$ alt., $01.08 .2013,2$ larvae, $U$. sp. (glabra or minor). Landkreis Nordsachsen: Kathewitz, nature reserve 'Alte Elbe Kathewitz', $51.516^{\circ} \mathrm{N}, 13.111^{\circ} \mathrm{E}, 85 \mathrm{~m}$ alt., 22.07 .2014 , more than 50 Ulmus controlled, but only 2 feeding traces of early instar larvae found; Schkeuditz, nature reserve 'Lup-

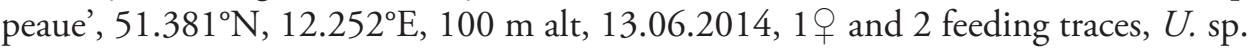

Saxony-Anhalt: Landkreis Aschersleben-Staßfurt: Westeregeln, $51.960^{\circ} \mathrm{N}$, $11.386^{\circ}$ E, 06.07.2014, feeding traces, U. sp. Landkreis Saalkreis: Sietzsch E, rest area 'Kapellenberg' on highway A9, $51.492^{\circ} \mathrm{N}, 12.204^{\circ} \mathrm{E}, 110 \mathrm{~m}$ alt., 07.08.2013, 2 feeding traces, U. minor.

The altitudinal range of the 66 study sites in Germany where A. leucopoda was observed, varies from 20-425 m above sea level (elevation determined using Google Earth where no original data were available). 51 observations were made below $100 \mathrm{~m}$ altitude. These comprise most of the data from Berlin, Brandenburg, MecklenburgWest Pomerania and Saxony-Anhalt. All five records from Bavaria were at over $300 \mathrm{~m}$ altitude. In Austria, A. leucopoda was found between 160-580 m altitude (Blank et al. 2010; E. Altenhofer, unpublished data).

The press release by Senckenberg, requesting observations of $A$. leucopoda from citizen scientists (Bartel 2013), was published in more than 300 print and online media primarily in Germany, but also in neighbouring German-speaking countries. During the following months, 23 persons responded by contacting ADL and SMB. Observations by three persons (among them TK and TP) were actually of $A$. leucopoda, whereas those of 20 persons related to other insects, plant species other than elms, or were ambiguous. As a result of the press release we were able to include 17 additional sites in this study, including the report of the severe outbreak in Schlieben and the most northern occurrence in Mecklenburg-West Pomerania, together with observations made on 13 elm species and cultivars, of which five were previously unrecorded as hosts.

\section{Infestation of elm species and cultivars}

At several localities all three Ulmus species which are autochthonous to Germany were present. Where A. leucopoda was found at such places, it was more abundant on U. minor 
Table I. Infestation of elm species, varieties and cultivars by Aproceros leucopoda: Number of study sites in Germany with [+] or without [-] larvae, larval feeding traces or cocoons attached to the tree. Observations from 2011-2014. Only unambiguously identified elm species, varieties and cultivars are listed. The cultivars 'New Horizon', 'Rebona' and 'Regal' belong to the 'Resista' series.

\begin{tabular}{c|c|c}
\hline Species or sort of elm & + & - \\
\hline Ulmus crassifolia & & 1 \\
\hline Ulmus davidiana var. japonica & 12 & 36 \\
\hline Ulmus glabra & & 1 \\
\hline Ulmus glabra 'Pendula' & & 21 \\
\hline Ulmus $\times$ hollandica & & 1 \\
\hline Ulmus laevis & 11 & 8 \\
\hline Ulmus lamellosa & 1 & \\
\hline Ulmus minor & 1 & 1 \\
\hline Ulmus minor var. suberosa & & \\
\hline Ulmus minor 'Webbiana' & & 1 \\
\hline Ulmus minor 'Wredei' & 5 & 2 \\
\hline Ulmus multinervis & & \\
\hline Ulmus 'New Horizon' & 2 & 2 \\
\hline Ulmus parvifolia & 2 & \\
\hline Ulmus pumila var. arborea & 1 & \\
\hline Ulmus 'Rebona' & 6 & \\
\hline Ulmus 'Regal' & & \\
\hline Ulmus 'Resista' & & \\
\hline & & \\
\hline
\end{tabular}

than on U. glabra. Also the total number of observation sites with infestations on U. minor is significantly higher than that on $U$. glabra (chi-squared test, $\mathrm{n}=71$ records including varieties and cultivars [Table 1], $\left.\chi^{2}=7.79, \mathrm{p}<0,01\right)$. Despite careful searches of $U$. laevis, no feeding traces or larvae were found. A very few feeding traces were seen on a single elm labelled "U. laevis" in Berlin Botanic Garden growing near other specimens under the same name which bore no traces. However, the tree with the feeding traces possessed some characters which are not typical for $U$. laevis, so there is doubt about its identity.

Aproceros leucopoda was found on several occasions feeding on Resista elms. These cultivars have not previously been recorded as hosts. No clear pattern of difference in abundance of $A$. leucopoda was observed amongst these cultivars, of which three were identified as $U$. 'New Horizon', $U$. 'Regal' and $U$. 'Rebona'. Ulmus minor 'Webbiana' and $U$. minor var. suberosa were recorded as new hosts for $A$. leucopoda, and $U$. davidiana var. japonica (previous records only from Japan) and $U$. pumila var. arborea (previous records only from Hungary) were confirmed as hosts (Table 1). No signs of feeding were found on U. crassifolia, U. glabra 'Pendula', U. lamellosa, U. $\times$ hollandica, U. multinervis and $U$. parvifolia, nor on Zelkova species (Ulmaceae) partly growing close to Ulmus.

At most localities, comparatively low population levels were found, with insignificant damage to the hosts. Elms at such localities were at the edges of woodland or within areas of human settlement, i.e., in more or less sheltered positions. Serious 


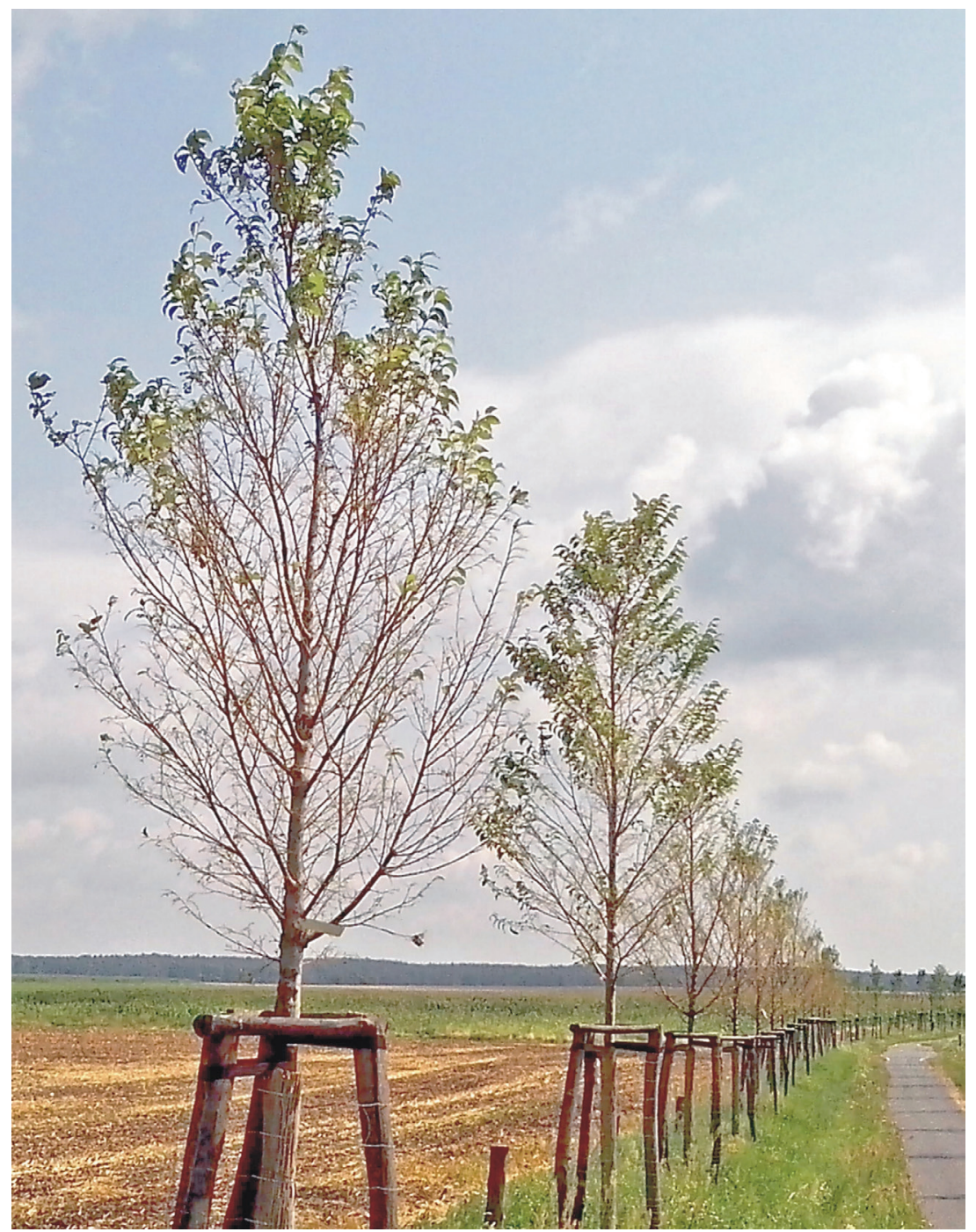

Figure 2. Feeding damage caused by Aproceros leucopoda on planted Ulmus 'Resista' during an outbreak between Schlieben and Kolochau (Brandenburg). Photo: LELF/Pfannenstill.

defoliation has so far been recorded in Germany only at Schlieben (Brandenburg, Landkreis Elbe-Elster). Surrounded by open agricultural areas, 235 trees of $U$. 'New Horizon' were planted here as a three kilometre long avenue along a road and a bicycle path in 2012. The trees originated from a nursery in the state of Schleswig-Holstein. Aproceros leucopoda could neither be observed in this particular nursery (A. Frers, personal communication) nor at other sites in this state. This outbreak was first detected in 2013 but the infestation was much less severe in 2014. In 2013, damage was unevenly distributed within the plantation. Many trees suffered severe damage, ranging from partial defoliation of twigs to defoliation of most of the crown (Fig. 2). 35 solid-walled 


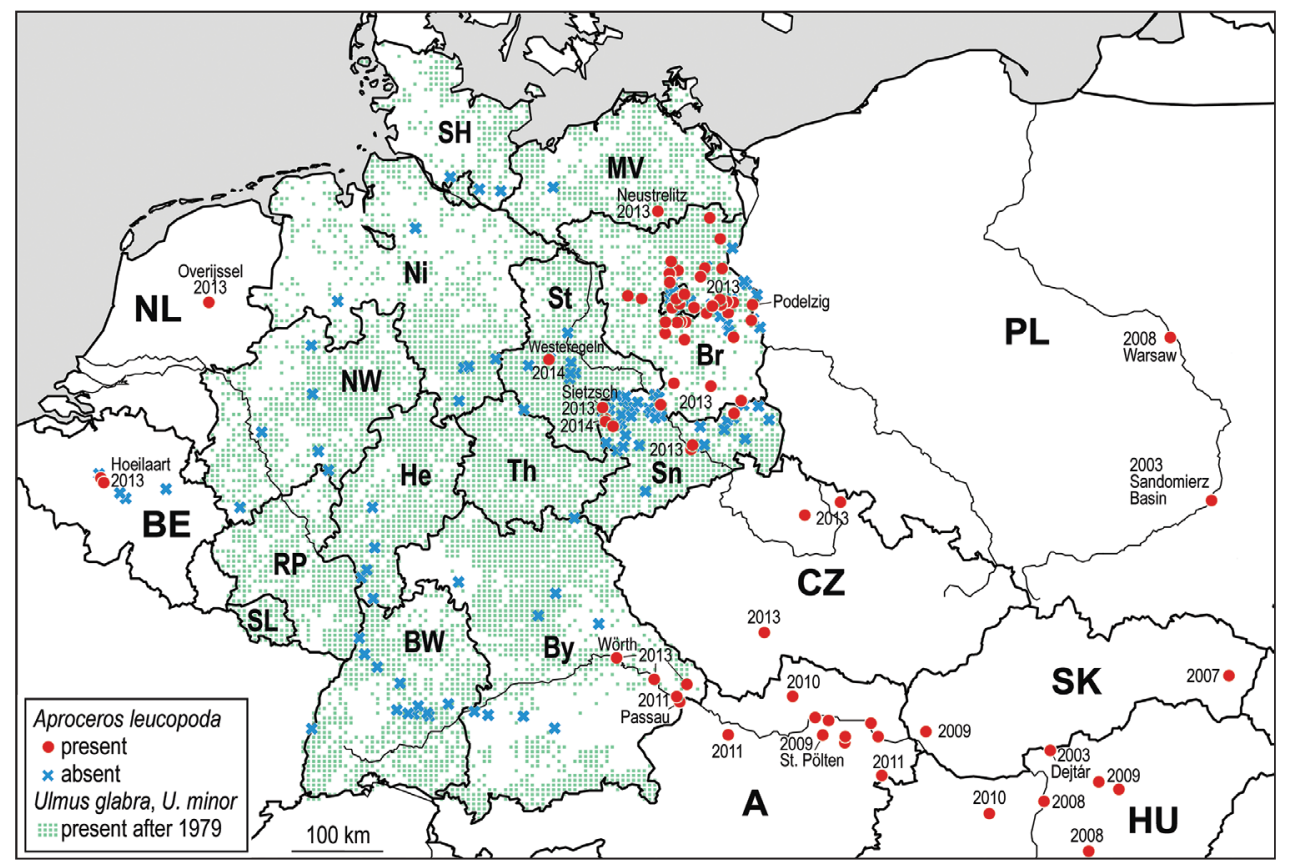

Figure 3. Distribution of Aproceros leucopoda in Germany, through 15.07.2014. Modified from Blank et al. (2009), including additional data for Austria (own data, Kraus et al. 2011), Belgium (Boevé 2013), the Czech Republic (own data, Jurášková et al. 2014), Germany (own data, Kraus et al. 2012, Pimpl 2014, Sobczyk and Nuss 2014), Hungary (Haris 2010) and the Netherlands (Mol and Vonk 2013). Distribution of Ulmus glabra and U. minor in Germany after BfN and NetPhyD (2013). German states are labelled with the abbreviations used in the checklist of the sawflies of Germany (Blank et al. 2001): Br - Brandenburg and Berlin, By - Bavaria, BW - Baden-Wurttemberg, He - Hesse, MV - Mecklenburg-West Pomerania, Ni - Lower Saxony (Niedersachsen), NW - North Rhine-Westphalia, RP - Rhineland-Palatinate, SH - Schleswig-Holstein, SL - Saarland, Sn - Saxony, St - Saxony-Anhalt, Th - Thuringia. Countries outside Germany where A. leucopoda is recorded are labelled with the international vehicle registration codes. Graphics: SDEI/Blank.

cocoons were separated from a mixed sample of soil and litter taken from below three elm trees. A density of ca 29 cocoons $/ \mathrm{m}^{2}$ for overwintering specimens is calculated for this outbreak site. In spring 2014, eight females emerged between April 8-25 under outdoor conditions. A less severe outbreak occurred in Frankfurt/Oder (Brandenburg) in 2013, where $1-5 \%$ defoliation was observed on 39 of ca $100 U$. 'Resista' trees.

\section{Dispersal distances and invasion speed of Aproceros leucopoda}

In Europe A. leucopoda was first found in 2003 in the Sandomierz Basin of southeastern Poland and in Dejtár, northern Hungary (Blank et al. 2010). The following estimates of the invasion speed are based on the distances between presumed sources of subsequent 
dispersal represented by the earliest recorded Hungarian and Polish localities and the sites most distant from these where A. leucopoda has been observed in Germany:

- Sandomierz Basin (2003) to the most western recorded site, Westeregeln in Saxony-Anhalt (2014): distance $740 \mathrm{~km}$, invasion speed ca $70 \mathrm{~km} / \mathrm{yr}$;

- Sandomierz Basin (2003) to the most northern recorded site, Neustrelitz in Mecklenburg-West Pomerania (2013): distance $660 \mathrm{~km}$, invasion speed ca $65 \mathrm{~km} / \mathrm{yr}$;

- Dejtár (2003) to the most southeastern recorded site, Passau in Bavaria (2011) (Kraus et al. 2012): distance $440 \mathrm{~km}$, invasion speed ca $55 \mathrm{~km} / \mathrm{yr}$.

In the following cases the annual speed of invasion is calculated from the distance between the closest neighbouring sites, where $A$. leucopoda was recorded only a few years later:

- Warsaw in Poland (2008) (Blank et al. 2010) to the closest recorded German site, Podelzig in eastern Brandenburg (2013): distance $450 \mathrm{~km}$, invasion speed ca $90 \mathrm{~km} / \mathrm{yr}$;

- St. Pölten in Austria (2009) (Blank et al. 2010) to the most southeastern recorded German site, Passau in Bavaria (2011): distance $170 \mathrm{~km}$, invasion speed ca $85 \mathrm{~km} / \mathrm{yr}$;

- from the most southern recorded Bavarian site near Passau (2011) to the most northern recorded Bavarian site, near Wörth (2013): distance $90 \mathrm{~km}$, invasion speed ca $45 \mathrm{~km} / \mathrm{yr}$.

In 2013 A. leucopoda was observed for the first time in Belgium (Boevé 2014) and the Netherlands (Mol and Vonk 2013). The following are the minimum and maximum distances between these sites and the closest German records known in 2013:

- Overijssel in the Netherlands to Sietzsch in Saxony-Anhalt, Germany: 360 km;

- Hoeilaart in Belgium to Wörth in Bavaria, Germany: 610 km.

\section{Discussion and conclusions}

Among the native elm species of Germany, Aproceros leucopoda clearly prefers Ulmus glabra and $U$. minor as larval hosts (Table 1 ), since no feeding has been observed on $U$. laevis. On a mixed stand of all three elm species in Lower Austria (Traismauer), $U$. laevis showed a very low infestation even during an outbreak of A. leucopoda (E. Altenhofer, personal observation). A number of additional elm species and cultivars must now be considered to be larval hosts. These were introduced to Germany as ornamental trees in horticulture, for afforestation, or planted in botanical gardens for scientific purposes. Feeding could not so far be observed on seven of the taxa listed in Table 1. However, in these cases, it would be premature to conclude that they are not potential hosts, because each of these species and cultivars was studied at only a single site. 
Some of the Resista ${ }^{\circledR}$ hybrid elms now prove to be suitable hosts. These cultivars, of complex hybrid parentage, were created to meet the demand for elms which are resistant to the fungal diseases commonly referred to collectively as "Dutch elm disease". Ulmus 'New Horizon' and $U$. 'Regal' are at present respectively the most often and the second most often planted elms of this sort in Germany (Mackenthun 2010). They are usually planted in settings where they are highly visible to the public, such as along roads and in city parks. Aside from possible effects on the health of the affected trees, defoliation by A. leucopoda will impair their aesthetic value. That 'New Horizon' and 'Regal' are acceptable hosts to A. leucopoda is not surprising, because U. pumila and U. japonica figure prominently in the parentage of both (Mackenthun 2010). Ulmus pumila is known to be highly susceptible to attack by A. leucopoda (e.g., Wu 2006, Blank et al. 2010, Cao et al. 2011), whilst $U$. japonica is a known host in Japan (Blank et al. 2010) and recorded here for the first time as a host in Europe.

The range of $A$. leucopoda in Germany currently comprises two separate areas (Fig. 3). The northern one extends from southern Mecklenburg-West Pomerania in the north to central Saxony in the south and from central Saxony-Anhalt in the west to the Polish border in the east. The second, southern area covers part of southeast Bavaria. These two large areas of occurrence do not at present appear to be confluent. The distribution of $U$. glabra, one of the two preferred native elm species, covers the low mountain ranges of central Germany (BfN and NetPhyD 2013). Although autochthonous $U$. glabra and $U$. minor have disappeared in several regions (BfN and NetPhyD 2013), their combined, largely continuous distribution throughout Germany (Fig. 3) provides the opportunity for $A$. leucopoda to spread further into more westerly parts of the country.

The northern distribution area of A. leucopoda in Germany is mostly within the North German Plain, which in the south is delimited by the low mountain ranges of central Germany. Judging from available distribution data (Blank et al. 2010, Mol and Vonk 2013, Boevé 2014, Sobczyk and Nuss 2014, Juraskova et al. 2014, present data), A. leucopoda has been recorded only rarely above $400 \mathrm{~m}$ altitude in central Europe. From Austria into Bavaria, A. leucopoda has spread along the valley of the river Danube, where A. leucopoda was found at a maximum altitude of $580 \mathrm{~m}$ near Zwettel, Lower Austria (E. Altenhofer, personal communication). The Alps to the south and the Bohemian Massif to the north of the valley possibly work as barriers. Future observations may reveal whether the low mountain ranges of central Germany will slow down or restrict the dispersal of $A$. leucopoda, despite the general presence there of at least U. glabra.

Apart from range expansion through self-dispersal of imagines, it seems likely that individuals can sometimes be accidentally transported by human agency over much greater distances with road, rail, air and canal traffic (Blank et al. 2010). Trade by nurseries of infested plants throughout a wide geographic area might also have a significant impact, but we could not observe such an event involving $A$. leucopoda. The occurrences in Belgium (Boevé 2014) and in the Netherlands (Mol and Vonk 2013) seem likely to belong in the category of human-mediated jump dispersal (Suarez et al. 
2001), because the gap of 360-610 km between these western records and the records in eastern Germany was unsuccessfully searched by us for signs of $A$. leucopoda in 2012 and 2013 (Fig. 3). Contrarily, the two observed distribution areas in Bavaria and in the northeastern German states should be explained by self-dispersal of $A$. leucopoda originating from the neighbouring countries Austria, Poland and possibly the Czech Republic, although human-mediated jump dispersal cannot be ruled out as a component within self-dispersal. Records made during consecutive years in Austria indicate a stepwise spread in a westerly direction (Fig. 3). Although comparable data from western Poland are missing, we suppose that self-dispersal also took place here, because the speeds of annual dispersal calculated from the distance between the Polish and the eastern German records (65-90 km/yr) are similar to speeds calculated from Austrian, Hungarian and Bavarian records ( $45-85 \mathrm{~km} / \mathrm{yr}$ ). The common distribution area of the preferred native larval hosts, $U$. glabra and $U$. minor, is more or less continuous from Germany to Hungary and to Poland (Meusel et al. 1965, BfN and NetPhyD 2013), which has facilitated the self-dispersal of $A$. leucopoda in a westerly direction.

The 2013 observations from southeastern Bavaria indicate an apparently limited speed of range extension $(45 \mathrm{~km} / \mathrm{yr})$ in that area since A. leucopoda was first recorded near Passau in 2011 (Kraus et al. 2012), although the total of study sites in Bavaria is comparatively low. Contrastingly, range expansion into northeastern Germany seems to have been both more rapid and extensive. At the majority of German localities, a low number of feeding traces made by young larvae were often the only signs that the species was present, perhaps indicating that colonisation had recently taken place. The inconspicuous damage may also have been a reason for the low number of replies by citizen scientists in response to our press release in 2013 (Bartel 2013). If the spread of A. leucopoda into eastern Germany is nevertheless assumed to have depended purely on natural dispersal of imagines, the distance (ca $220 \mathrm{~km}$ ) between the most westerly recorded locality (Westeregeln) and the Polish border (Podelzig) indicates that the first female may already have arrived in northeastern Germany two to five years before 2013.

Very little is known about the dispersal ability of sawflies and horntails (Hymenoptera 'Symphyta') in general, or the time scales and distances associated with the spread of individual species undergoing range expansion. The speed of annual range expansion resulting from self-dispersal of 45-90 km/yr estimated here for $A$. leucopoda lies within the range known for a few sawflies and for other insects. Nematus oligospilus Förster, 1854 (Tenthredinidae), a sawfly species invasive to New Zealand with larvae feeding on willow, extended its range through the North Island at $300 \mathrm{~km} / \mathrm{yr}$ (Charles and Allan 2000; ca $165 \mathrm{~km} / \mathrm{yr}$ measured as a straight line). In South America Ovruski and Fidalgo (1991) observed a range expansion of $300 \mathrm{~km} / \mathrm{yr}$ also for $N$. desantisi D.R. Smith, 1983, which might be conspecific with $N$. oligospilus from New Zealand (Koch and Smith 2000). Ovruski and Fidalgo (1991) supposed passive transport to be a possible component of the dispersal. Gilpinia hercyniae (Hartig, 1837) (Diprionidae) is invasive to the Nearctic, where its larvae damage spruce trees (Picea spp.). The speed of range expansion in Canada is given as $50 \mathrm{~km} / \mathrm{yr}$ (CABI 2014). The average speed for Sirex noctilio Fabricius, 1793 (Siricidae), a woodwasp invasive in South America, has 
been estimated as 30-50 km/yr (Yemshanov et al. 2009). Smith (1996) summarized distribution data for the invasive Asian woodwasp Eriotremex formosanus (Matsumura, 1912), which in the United States was first observed in southern Georgia and in northern Florida in 1974. E. formosana was found 15 years later in southeastern Virginia, about $740 \mathrm{~km}$ distant from these earliest sites (ca $50 \mathrm{~km} / \mathrm{yr}$ ) and 16 years later in eastern Texas, $990 \mathrm{~km}$ distant (ca $60 \mathrm{~km} / \mathrm{yr}$ ). However, S. noctilio and E. formosanus differ greatly from the Aproceros, Gilpinia and Nematus species in several ways, e.g., in the large body and the larval feeding habit inside solid wood. Sirex noctilio reproduces sexually and usually produces at most one generation per year (Eichhorn 1982), whereas E. formosanus is apparently parthenogenetic in the US and supposedly has two generations per year, based on phenological data (Smith 1996). Compared to the range expansion of 30-60 km/yr resulting from self-dispersal of these woodwasps, not even the highest estimated speed of $90 \mathrm{~km} / \mathrm{yr}$ for $A$. leucopoda seems excessive, because several life traits of $A$. leucopoda promote rapid dispersal: it reproduces parthenogenetically, has up to four generations per year, and the larvae are external feeders on leaves (Blank et al. 2010), which appear more nutritious than wood infested by fungi. Among insects other than Hymenoptera, Brown et al. (2008) calculated an invasion speed of 58-145 $\mathrm{km} / \mathrm{yr}$ for Harmonia axyridis (Pallas, 1771) (Coleoptera, Coccinellidae) in Europe. The considerably higher speed of $500 \mathrm{~km} / \mathrm{yr}$ estimated for this species in South Africa (Stals 2010) probably includes jump-dispersal events. The speed of range expansion in Cameraria obridella Deschka \& Dimić, 1986 (Lepidoptera, Gracilariidae) in central and western Europe was estimated to be 60-70 km/yr based on the dates of first observations in European countries (Šerfová and Laštůvka 2001), although these authors also cite much lower speeds for other moths. For $C$. ohridella both active dispersal and passive transport by wind and man were considered to play a role.

The rapid range expansion of $A$. leucopoda throughout Europe predicted by Blank et al. (2010) is evidently taking place, and likely to progress. Although occurrences in Germany have so far seldom resulted in severe defoliation, this may only be because population levels still have not peaked. The considerable differences in climate between the European territories which it has already colonised, together with the altitudinal range inhabited by the species, suggest that it should easily be able to spread through most of Europe where elms grow (Meusel et al. 1965). Whether it is possible in the long-term to exclude it from territories such as the British Isles or Scandinavia, which may be adequately protected by the sea from self-dispersal events, remains to be seen.

\section{Acknowledgements}

For the communication of additional observations we are grateful to Ewald Altenhofer (Etzen), Antje Frers (Ellerhoop), and Katrin Langner (Ludwigsfelde). Marko Prous (Müncheberg) assisted ADL and SMB with fieldwork. David R. Smith (Washington) quickly supplied the missing copy of Ovruski and Fidalgo (1991). Gordon Mackenthun (Leipzig) kindly helped with the identification of some elm specimens. The volunteers 
contributing to the Flora of Germany as well as the Bundesamt für Naturschutz and the Netzwerk Phytodiversitaet Deutschland are acknowledged for freely providing distribution data of the elms in Germany. Thomas Schmitt (Müncheberg), Marko Prous, David R. Smith, and an anonymous referee checked earlier versions of the manuscript and helped to improve it.

\section{References}

Anonymous (2013) Elm sawfly-zigzag in the Moscow region. Russian Research Institute for Silviculture and Mechanization of Forestry (VNIILM). http://www.vniilm.ru/en/news/4192013-07-09 [in Russian, accessed on 31.08.2013]

Artokhin KS, Ignatova PK, Terskov EN (2012) New insects including invasive species for the fauna of Rostov Region (Russia). Caucasian Entomological Bulletin 8: 199-202. http:// ssc-ras.ru/files/files/2_Artokhin.pdf [in Russian, English abstract].

Barbier Y, Rasmont P (1996) Carto Fauna-Flora (CFF) version 1.2. Université de Mons-Hainaut. Bartel R (2013) Eingeschleppt: Zickzack-Blattwespe bei Berlin entdeckt. Senckenberg Press Releases. http://www.senckenberg.de/root/index.php?page_id=5206\&PHPSESSID=mk4 nca52sj7p44uj10146v774rfjhc0v\&kid=2\&id=2743 [accessed on 31.05.2013]

$\mathrm{BfN}$ and NetPhyD [Bundesamt für Naturschutz \& Netzwerk Phytodiversitaet Deutschland] (2013) Datenbank FLORKART der Floristischen Kartierung Deutschlands. http://www. floraweb.de [accessed on 21.07.2014; free use of data for scientific purpose licensed under the provisions of CC BY-NC-SA 3.0 DE]

Blank SM, Deters S, Drees M, Jänicke M, Jansen E, Kraus M, Liston AD, Ritzau C, Taeger A (2001) Symphyta. In: Dathe HH, Taeger A, Blank SM (Eds) Verzeichnis der Hautflügler Deutschlands (Fauna Germanica 4). Entomologische Nachrichten und Berichte Beiheft 7: 8-27.

Blank SM, Hara H, Mikulás J, Csóka G, Ciornei C, Constantineanu R, Constantineanu I, Roller L, Altenhofer E, Huflejt T, Vétek G (2010) Aproceros leucopoda (Hymenoptera, Argidae): An East Asian pest of elms (Ulmus spp.) invading Europe. European Journal of Entomology 107: 357-367. doi: 10.14411/eje.2010.045

Blank SM, Gninenko YI, Telegina OS (2011) New invasive sawfly Arge captiva in Kazachstan. Zertteushi - Issledovatel' (Astana and Shymkent) 2011(1-2 (57-58)): 131-134. [in Russian, abstract in Kazakh and English]

Boevé J-L (2014) First record in Belgium of the invasive sawfly Aproceros leucopoda (Hymenoptera, Argidae) and some related ecological data. Bulletin de la Société Royale Belge d'Entomologie 149[2013]: 217-221.

Brown PMJ, Roy HE, Rothery P, Roy DB, Warwe RL, Majerus MEN (2008) Harmonia axyridis in Great Britain: analysis of the spread and distribution of a non-native coccinellid. BioControl 53: 55-67. doi: 10.1007/978-1-4020-6939-0_2

Brummerstedt E, Kristensen A, Nielsen R, Bille-Hansen V (1987) Death of a puppy after eating sawfly larvae. Case report. Dansk Veterinaertidsskrift 70: 758-760. [in Danish, English abstr.] 
CABI (2014) Gilpinia hercyniae. In: Invasive Species Compendium. Datasheets, maps, images, abstracts and full text on invasive species of the world. http://www.cabi.org/isc/datasheet/25211 [accessed 27.07.2014]

Cao JF, Lin CS, Wu FY, Zhang HX, Zhao WJ (2011) Bionomics and control of Aproceros leucopoda. Forest Pest and Disease [2011](6): 17-20. http://en.cnki.com.cn/Article_en/ CJFDTOTAL-SLBC201106004.htm [in Chinese, abstract in Chinese and English]

Charles J, Allan DJ (2000) Development of the willow sawfly, Nematus oligospilus, at different temperatures, and an estimation of voltinism throughout New Zealand. New Zealand Journal of Zoology 27: 197-200. doi: 10.1080/03014223.2000.9518226

de Groot M, Hauptman T, Seljak G (2012) The first record of the invasive "zigzag" sawfly, Aproceros leucopoda (Hymenoptera: Argidae) in Slovenia. Gozdarski Vestnik 70: 3-7. [in Slovenian, English abstract]

Eichhorn O (1982) Familienreihe Siricoidea. In: Schwenke W (Ed.) Die Forstschädlinge Europas. Paul Parey, Hamburg, Berlin, 4: 196-231.

EPPO [European and Mediterranean Plant Protection Organization] (2014) Aproceros leucopoda (Hymenoptera: Argidae). Zigzag elm sawfly. In: EPPO Alert List. http://www.eppo.int/ QUARANTINE/Alert_List/insects/aproceros_leucopoda.htm [accessed 02.07.2014]

Hara H, Shinohara A (2008) Taxonomy, distribution and Life History of Betula-feeding sawfly, Arge pullata (Insecta, Hymenoptera, Argidae). Bulletin of the National Museum of Nature and Science, Series A (Zoology) 34: 141-155.

Haris A (2010) Sawflies of the Vértes Mountains (Hymenoptera: Symphyta). Natura Somogyiensis 17: 221-250.

Jurášková M, Hradil K, Macek J (2014) Pilatěnka Aproceros leucopoda-nový invazní škůdce v České republice. Rostlinolékař 3/2014: 21-23. [in Czech]

Kannan R, Oelrichs PB, Thamsborg SM, Williams DH (1988) Identification of the octapeptide lophyrotomin in the European birch sawfly (Arge pullata). Toxicon 26: 224-226. doi: 10.1016/0041-0101(88)90177-8

Koch F, Smith DR (2000) Nematus oligospilus Förster (Hymenoptera: Tenthredinidae), an introduced willow sawfly in the southern hemisphere. Proceedings of the entomological Society of Washington 102: 292-300.

Kraus M, Liston AD, Taeger A (2012) Die invasive Zick-Zack-Ulmenblattwespe Aproceros leucopoda Takeuchi, 1939 (Hym., Argidae) in Deutschland. DGaaE Nachrichten 25[2011]: 117-119. http://www.dgaae.de/files/dgaae/downloads/DgaaE\%20Nachrichten/nach25_3.pdf

Mackenthun G (2010) Handbuch der Ulmengewächse. http://www.ulmen-handbuch.de [accessed on 15.07.2014]

Matošević D (2012) First record of elm sawfly (Aproceros leucopoda), new invasive species in Croatia. Sumarski List 136: 57-61. [in Croatian, English abstract]

Meusel H, Jäger E, Weinert E (1965) Vergleichende Chorologie der zentraleuropäischen Flora. Karten. Gustav Fischer, Jena, 258 pp.

Mol A, Vonk D (2013) De iepenzigzagbladwesp: een nieuwe exoot in Nederland. natuurbericht.nl, http://www.natuurbericht.nl/?id=12191 [accessed 20.02.2014]

Ovruski S, Fidalgo P (1991) Distribución geografica de Nematus desantisi Smith (Hymenoptera: Tenthredinidae), plaga de salicaceas. Ciência e Cultura Supplement 43(7): 36-37. 
Pimpl F (2014) Erstfund der Zickzack-Blattwespe Aproceros leucopoda Takeuchi, 1939 (Hym.: Argidae) im Erzgebirge. Mitteilungen Sächsischer Entomologen 33: 22, 59.

Pschorn-Walcher H (1982) Unterordnung Symphyta, Pflanzenwespen. In: Schwenke W (Ed.) Die Forstschädlinge Europas. Paul Parey, Hamburg and Berlin, 4: 4-196 and 232-234.

Schrader G, Schröder T (2013) Express-PRA zu Aproceros leucopoda. Julius-Kühn-Institut, Bundesforschungsanstalt für Kulturpflanzen, Risikoanalysen. http://pflanzengesundheit. jki.bund.de/index.php?menuid=57 [accessed 02.07.2013]

Šerfová H, Laštůvka Z (2001) Dispersal of the horse-chestnut leafminer, Cameraria ohridella Deschka \& Dimić, 1986, in Europe: its course, ways and causes (Lepidoptera: Gracilariidae). Entomologische Zeitschrift 111: 194-198.

Shinohara A, Hara H, Kim JW (2009) The species-group of Arge captiva (Insecta, Hymenoptera, Argidae). Bulletin of the National Museum of Nature and Science, Series A (Zoology) 35: 249-278.

Smith DR (1996) Discovery and spread of the asian horntail, Eriotremex formosanus (Matsumura) (Hymenoptera: Siricidae), in the United States. Journal of Entomological Science 31: 166-171. http://src.fabinet.up.ac.za/sirex/sirexlit/Smith1996JnlEntomolSci.pdf

Sobczyk T, Nuss M (2014) Nachweise der Zickzack-Blattwespe Aproceros leucopoda (Takeuchi, 1939) in Sachsen (Hymenoptera: Symphyta: Argidae). Sächsische Entomologische Zeitschrift 7: 35-38.

Stals R (2010) The establishment and rapid spread of an alien invasive lady beetle: Harmonia axyridis (Coleoptera: Coccinellidae) in southern Africa, 2001-2009. IOBC/wprs Bulletin 58: 125-132. http://www.academia.edu/582044/STALS_R._2010._The_establishment_and_rapid_spread_of_an_alien_invasive_lady_beetle_Harmonia_axyridis_Coleoptera_Coccinellidae_in_southern_Africa_2001-2009._IOBC_wprs_Bulletin_58_125-132

Suarez AV, Holway DA, Case TJ (2001) Patterns of spread in biological invasions dominated by long-distance jump dispersal: Insights from Argentine ants. PNAS 98: 1095-1100. doi: 10.1073/pnas.98.3.1095

Taeger A, Altenhofer E, Blank SM, Jansen E, Kraus M, Pschorn-Walcher H, Ritzau C (1998) Kommentare zur Biologie, Verbreitung und Gefährdung der Pflanzenwespen Deutschlands (Hymenoptera, Symphyta). In: Taeger A, Blank SM (Eds) Pflanzenwespen Deutschlands (Hymenoptera, Symphyta). Kommentierte Bestandsaufnahme. Goecke \& Evers, Keltern, 49-135.

Taeger A, Blank SM, Liston AD (2006) European Sawflies (Hymenoptera: Symphyta) - A Species Checklist for the Countries. In: Blank SM, Schmidt S, Taeger A (Eds) Recent Sawfly Research: Synthesis and Prospects. Goecke \& Evers, Keltern, 399-504.

Taeger A, Blank SM, Liston AD (2010) World Catalog of Symphyta (Hymenoptera). Zootaxa 2580: 1-1064. http://www.mapress.com/zootaxa/2010/1/zt02580p1064.pdf

Thamsborg SM, Jørgensen RJ, Brummerstedt E (1987) Sawfly poisoning in sheep and goats. Veterinary Record 121: 253-255. doi: 10.1136/vr.121.11.253

Timuş A, Derjanschi V, Croitoru N (2008) Viespea neagră a ulmului (Arge sp.) în Republica Moldova şi dezvoltarea acesteia pe ulmul de câmp - Ulmus minor. Mediul Ambiant 4: 35-37. http://www.clima.md/files/CercetareSC/Publicatii/Mediul\%20Ambiant\%20nr\%204\%20 August\%202008\%20Cazac\%20Boian.pdf [in Romanian, English abstract] 
Wu XY (2006) Studies on the biology and control of Aproceros leucopoda. Plant Protection (Beijing) 32: 98-100. [in Chinese]

Yemshanov D, McKenney DW, de Groot P, Haugen D, Sidders D, Joss B (2009) A bioeconomic approach to assess the impact of an alien invasive insect on timber supply and harvesting: a case study with Sirex noctilio in eastern Canada. Canadian Journal of Forest Research 39: 154-168. doi: 10.1139/X08-164

Zandigiacomo P, Cargnus E, Villani A (2011) First record of the invasive sawfly Aproceros leucopoda infesting elms in Italy. Bulletin of Insectology 64: 145-149. http://www.bulletinofinsectology.org/pdfarticles/vol64-2011-145-149zandigiacomo.pdf

Zöfel P (1988) Statistik in der Praxis. UTB 1292, Gustav Fischer, Stuttgart, 426 pp. 